\title{
Terapi Seni Melalui Melukis pada Pasien Skizofrenia dan Ketergantungan Narkoba
}

\author{
Sarie Rahma Anoviyanti
}

\begin{abstract}
For centuries, human used various forms and/or elements of art as an effort to 'treat' their body and souls. The ancient Greece used the existence of theatrical art as something that has catharsis effect in "cleansing" and/or "healing" their souls. Through this understanding, the author explores the effect of art activities on the process of mental recovery (art therapy). It is observed that through the process, catharsis effect serves as an important part of art therapy; exploring process and activities that unites disciplines of Art and Psychology as means for treatment.
\end{abstract}

Keywords: art therapy; mental disorders.

\section{Terapi Seni, Perpaduan Dua Buah Disiplin Ilmu}

Pada awalnya, seni dan psikologi dipandang sebagai dua hal berbeda yang tidak terdapat sangkut pautnya satu sama lain. Meskipun demikian, dalam perkembangannya, para ilmuwan mulai menemukan keterkaitan yang ada, antara seni dan psikologi. Perkembangan ilmu psikologi modern pun, bisa dibilang baru apabila dibandingkan dengan perkembangan ilmu pengetahuan yang lainnya. Psikologi modern baru muncul sekitar awal abad kedua puluh, sementara dalam kurun waktu yang sama, berbagai ilmu pengetahuan yang lainnya telah mencapai kemajuan yang pesat.

Sementara itu dalam perkembangannya, keterkaitan antara seni dan psikoanalisa, menjadi semakin mengemuka. Psikoanalisa, yang kemunculannya dipelopori oleh Sigmund Freud, kemudian menjadi semakin menguatkan hubungan antara teori seni dan psikologi, termasuk diantaranya teori-teori paling komprehensif dan berani tentang sumber dari dorongan artistik yang dikemukakan oleh Freud. Meskipun demikian, mungkin dikarenakan thesisnya begitu kuat dan satu prinsip digunakan untuk menjelaskan sekuruh dorongan artistik, teori-teori tersebut mudah dikritik. Telah banyak teori-teori yang muncul sesudahnya, membantah dan mengkritik teori Freud yang terlalu cenderung kepada dorongan biologis manusia.

Namun demikian, terlepas dari kelemahan-kelemahan tersebut, kerangka dasar dari teori Freud telah menopang pengertian modern tentang kepribadian, dan telah menjadi unsur-unsur hakiki kebudayaan Barat. Hubungan yang ada antara seni dan psikologi dijelaskan ruang lingkupnya dalam suatu cabang ilmu yang baru, yaitu suatu cabang keilmuan yang disebut Terapi Seni. 
Terapi seni secara harafiah dapat diartikan sebagai penggabungan dua buah disiplin ilmu, yaitu antara ilmu seni dan psikologi. Dengan demikian, istilah terapi seni, yang secara verbal terdiri dari kata Terapi dan Seni, secara nyata menggabungkan dua jenis disiplin ilmu, yaitu Seni (Art) dan Psikologi. [1] Menurut ahli psikologi dan terapi seni Judith Rubin, memberikan pernyataannya mengenai definisi terapi seni :

$"$ Art + Therapy $=?$ This formula conveys the equation that makes up art therapy - The blending of art and therapy. Art therapy is essentially the marriage of two disciplines; art and psychology. Aspects of the visual arts, among others, are important to the definition and scope of art therapy. Art therapy brings together all of these disciplines, making it difficult to understand at the first glances" (dalam Malchiodi, 1998)

Pernyataan tersebut juga menyatakan adanya suatu ambiguitas mengenai definisi terapi seni yang membingungkan, dikarenakan posisinya yang berusaha menengahi dua disiplin ilmu yang berbeda. Hingga saat ini, masih banyak pihak yang menganggap bahwa kedua disiplin ilmu tersebut tidak saling bersinggungan atau bahkan saling berkolaborasi. Stigma ini masih bertahan dibenak masyarakat menyebabkan masyarakat awam sulit untuk mengerti apa sebenarnya terapi seni itu. Bahkan masyarakat di dunia Barat, yang perkembangan ilmu terapi seninya sudah cukup maju pun masyarakatnya terkadang masih asing dengan istilah terapi seni. Hanya orang-orang yang berkecimpung di dunia terapi seni, dan yang telah mengalami berbagai kegiatan terapi seni yang paham benar mengenai apa dan yang seperti bagaimanakah terapi seni itu. Hal ini tentunya tidak lepas dari kolaborasi antara peneliti seni dan psikologi.

Pada umumnya, aktivitas terapi seni mungkin bagi masyarakat awam hanya terlihat seperti aktivitas kelas atau kursus seni rupa pada umumnya, namun sebenarnya terdapat perbedaan. Bagaimanapun juga pada aktivitas terapi seni proses kreatif lebih dipentingkan daripada kemampuan individu dalam menghasilkan karya seni yang sesungguhnya. Tujuan terapi seni bukanlah untuk menghasilkan karya seni yang estetik, ataupun untuk mengasah bakat untuk menghasilkan seorang seniman, akan tetapi tujuan akhir yang ingin dicapai oleh terapi seni adalah untuk membantu pasien agar merasa lebih nyaman terhadap diri mereka sendiri.

Dalam mengerjakan karya yang melibatkan kreativitas, semua emosi dan pikiran yang mengendap akan 'tereksternalisasi' atau tersalurkan, sehingga semua emosi dan pikiran tersebut pada akhirnya akan menjadi jelas akar permasalahannya karena terbacanya simbol-simbol dari bentuk yang ada pada karya tersebut, kadangkala dibentuk, baik secara sadar maupun tidak sadar 
memiliki makna yang berhubungan secara langsung dengan akar permasalahan yang sedang dihadapi oleh pasien tersebut.

Seni juga memiliki kemampuan untuk mencatat dan menyampaikan berbagai tingkatan emosi, dari rasa nyaman hingga kesedihan yang terdalam, dari kejayaan hingga trauma. Dari uraian ini dapat kita ambil kesimpulan bahwa, jika dilihat dalam ruang lingkup yang lebih luas lagi, seni telah menyediakan jalan bagi pemahaman, membuat suatu pengertian dan menjelaskan pengalaman batin (inner experiences) tanpa harus menjelaskan pengalaman tersebut dengan menggunakan kata-kata. Selain itu kemampuan menggambar pada dasarnya lebih kepada kemampuan yang bersifat naluriah dan intuitif.

\section{$2 \quad$ Melukis Sebagai Sebuah Bentuk Terapi}

Melukis sebagai terapi, berkaitan dengan aspek kontemplatif atau sublimasi. Kontemplatif atau sublimasi merupakan suatu cara atau proses yang bersifat menyalurkan atau mengeluarkan segala sesuatu yang bersifat kejiwaan, seperti perasaan, memori, pada saat kegiatan berkarya seni berlangsung. Aspek ini merupakan salah satu fungsi seni yang dimanfaatkan secara optimal pada setiap sesi terapi. Kontemplatif dalam arti, berbagai endapan batin yang ditumpuk, baik itu berupa memori, perasaan, dan berbagai gangguan persepsi visual dan auditorial, diusahakan untuk dikeluarkan atau disampaikan. Dengan demikian pasien tidak terjebak pada suatu situasi dimana hanya diri sendiri terjebak pada realitas imajiner yang diciptakan oleh diri sendiri. Aspek kontemplatif atau sublimasi inilah yang kemudian dikenal dengan istilah katarsis dalam dunia psikoanalisa.

Hal tersebut, juga sekaligus dapat menjadi media untuk mencari pemicu atau akar permasalahan melalui berbagai visualisasi atau simbol-simbol yang muncul selama terapi berlangsung. Berdasar visualisasi yang tercurah selama terapi berlangsung, seringkali tampak gambar beberapa image yang merupakan simbolisasi dari ekspresi bawah sadar dari pasien. Kemudian bagi terapis, beragam visualisasi inilah yang menjadi perangkat untuk menentukan diagnosa sampai sejauh apakah kerusakan kondisi kejiwaan pasien, dan pengobatan jenis apakah yang sesuai bagi pasien.

Paparan ini untuk mengungkap aspek penyembuhan gangguan mental melalui seni yaitu melukis, dan untuk mengetahui lebih jauh mengenai penelitian ini, yakni bagaimana aspek seni rupa, dapat membawa dan memberikan gambaran mengenai perubahan bagi kesehatan mental penderita. Penulis juga bermaksud menjelaskan fungsi senirupa sebagai elemen katarsis. Untuk mengetahui bagaimana aspek seni rupa, dapat membawa perubahan bagi kesehatan mental penderita. Tidak kalah pentingnya adalah kemajuan apapun dalam bidang 
terapi seni ini dapat menjadi sumbangan besar bagi kemajuan kedua disiplin ilmu, baik ilmu seni dan psikologi.

Penelitian dilakukan meliputi observasi lapangan melalui pengalaman berinteraksi langsung dengan penderita gangguan mental dan mencatat dan menganalisis segala bentuk perubahan yang terlihat pada saat proses berlangsung, studi pustaka mengenai terapi seni dan aspek-aspek lainnya yang terkait seperti teori tentang gangguan mental, teori terapi seni, kreativitas, dan sebagainya, wawancara dengan pakar dan ahli psikologi serta terapi seni untuk menunjang keabsahan data agar lebih akurat, selain itu, penulis juga melakukan pendekatan dari sudut pandang Psikoanalisa dan Kritik Seni dalam menganalisis sampel gambar karya pasien Skizofrenia dan pengguna narkoba.

\section{Lingkaran, Persegi, dan Segitiga (Aku, Lingkunganku, dan Tuhanku)}

Berdasarkan data sampel yang berasal dari arsip lembaga Madani Home Care, pada awal sesi terapi berlangsung umumnya, pada gambar tahap awal sesi terapi seni, pasien Skizofrenia menggambar gumpalan-gumpalan, atau lebih tepatnya mereka menggambar lingkaran masif yang pejal, seperti yang tampak pada gambar karya Yayan, salah satu pasien Skizofrenia di Lembaga rehabilitasi Madani Home Care.
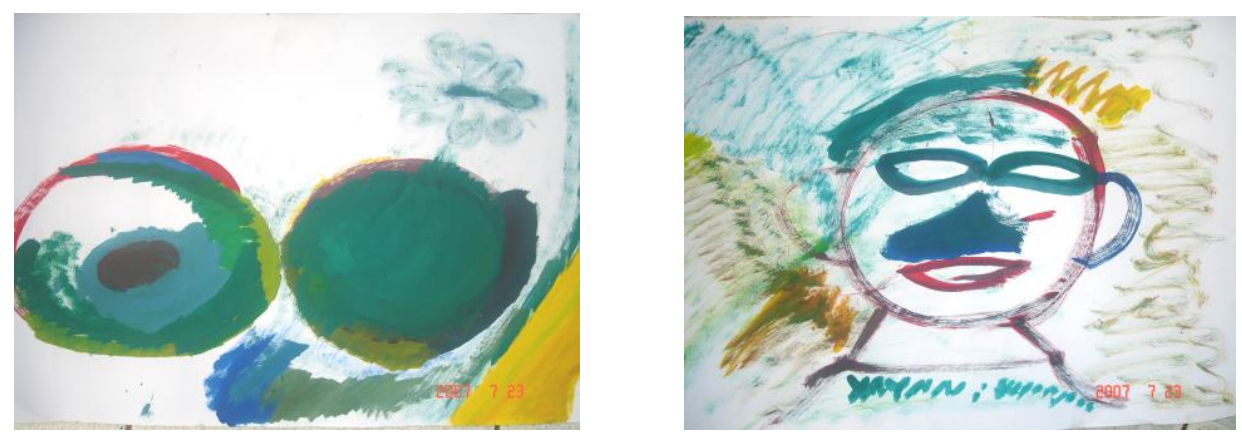

Gambar 1 Gambar pasien Skizofrenia, Yayan (20 thn.) tahap ke-1 dan ke- 11 (Sumber : Madani Home Care, 2004).

Beberapa ada yang memvisualisasikan bentuk lingkaran tersebut dengan cara abstrak, atau pun sebagai potret wajahnya dalam bentuk lingkaran. Atau pada kasus Aswin (21 tahun) dan Dian (19 tahun), yang mana keduanya, cenderung pada kasus Skizofrenia. Pada Aswin dan Dian, terdapat ciri dimana pada tahap awal sesi terapi, keduanya cenderung membagi-bagi bidang gambar pada beberapa bagian, dan menampakkan visualisasi berupa beragam warna yang 
terlihat tumpang tindih atau overlapping dalam sapuan kuas yang terkesan brutal.

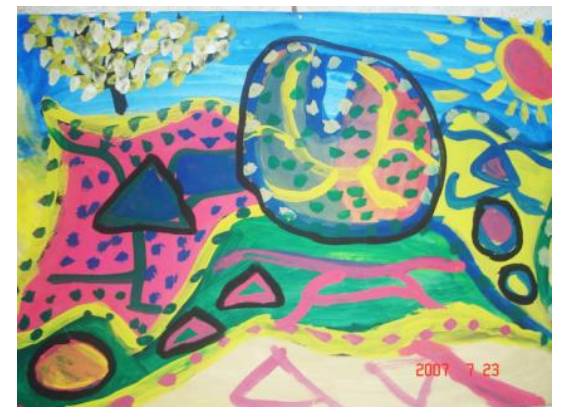

Gambar 2 Gambar pasien Skizofrenia, Aswin (21 thn.) tahap ke-2 (Sumber : Madani Home Care, 2004).

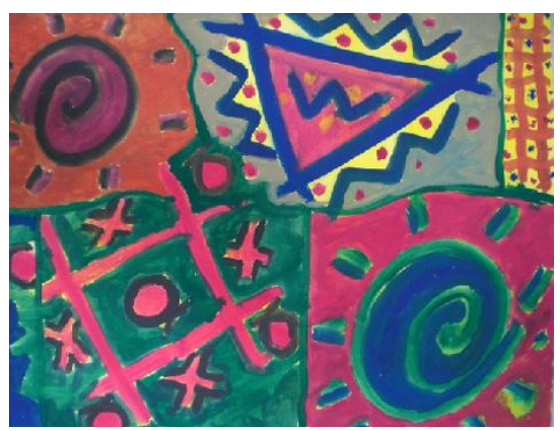

Gambar 3 Gambar pasien Skizofrenia, Dian (19 thn.) tahap ke-6 (Sumber : Madani Home Care, 2004)

Namun, pada umumnya seiring berjalannya sesi terapi, lingkaran itu mengendur dan mulai merespon bentuk-bentuk lain, yang pada umumnya cenderung geometris, dan pada fase selanjutnya mulai merujuk pada bentuk-bentuk realis, dan fase terakhir adalah dimana pasien mulai merepresentasikan keadaan alam sekitarnya atau bahkan merepresentasikan image orang-orang yang dirasakan penting dan dekat dengannya baginya, dalam arti aspek kesadaran telah terbangkitkan kembali. Hal ini dibuktikan pasien mampu merespon lingkungannya dengan sadar, dan menuangkannya kedalam karya visual. Bulatan yang sering muncul pada awal sesi merupakan representasi dari kondisi psikis pasien yang masih sepenuhnya terfokus pada dirinya sendiri.

Dengan kata lain, lingkaran, penulis asumsikan sebagai entitas diri yang masih terperangkap dalam dunia "inner self" nya sendiri. Seolah-olah menggumpal 
dalam satu bentuk yang solid dan tak terputus tanpa mampu melepaskan diri dari dunia inner self tersebut. Layaknya objek lingkaran, yang pada visualisasinya merupakan suatu bentuk yang memiliki karakteristik yang tak terputus (cycling). Namun seperti yang penulis jelaskan sebelumnya, ketika terjadi perbaikan mental dan fisik dalam selama proses terapi berlangsung, tampak dalam gambar, lingkaran tersebut mulai mengendur dan merespon bentuk-bentuk lain yang lebih dapat diidentifikasi.

Menurut R.M. Simon dalam bukunya, Symbolic Images in Art as Therapy, ia menyebutkan bahwa bahwa seorang bayi berusia kira-kira enam belas bulan telah mampu membuat sebuah lingkaran selain itu pula ia berpendapat bahwa :

"I have come to understand the Circle as a symbol of the Self, as an entity. Little children shows great persisitence in making Circles and, having mastered this, they soon need to embelish them in some way" (Simon, 1997) [2]

Selain itu kecenderungan memunculkan objek-objek dalam bentuk-bentuk dasar seperti lingkaran, segitiga, dan persegi, hampir pada setiap pasien dan setiap sesi muncul. Visualisasinya tampak timbul dan tenggelam (fluktuatif), dan juga divisualisasikan dalam berbagai gaya. Sementara pada pasien depresi yang diakibatkan oleh zat adiktif, pada awal sesi terapi mereka cenderung melukiskan bentuk-bentuk yang absurd, namun pada sesi terapi selanjutnya, mereka lebih mampu menampilkan beberapa bentuk yang dapat diidentifikasi, meskipun jika dilihat berdasarkan komposisinya masih terlihat absurd.

Selain lingkaran, seperti dijelaskan di atas, juga tampak bentuk-bentuk geometris dasar seperti persegi dan segitiga. Menurut R.M. Simon dalam bukunya, Symbolic Images In Art As Therapy, bentuk persegi merupakan bentuk orisinal yang melingkupi lingkaran. Ia berpendapat bentuk persegi yang tampak melingkupi lingkaran, memberi kesan seolah bentuk persegi tersebut tampak seperti tembok yang membatasi lingkaran.

Komposisi ini, menyimbolkan keberadaan "Self"dalam relasinya terhadap segala sesuatunya yang bukan "Aku". Lingkaran dalam persegi adalah bentuk integrasi image yang paling dini, yang melambangkan kebutuhan kita untuk menjadi diri kita sendiri, selain itu juga merujuk pada kebutuhan untuk terhubung dengan dunia luar, dan disaat yang bersamaan juga memisahkan diri darinya sedangkan untuk bentuk segitiga, penulis berasumsi bahwa simbol tersebut erat kaitannya dengan transendensi Ilahiah. Atau dengan kata lain terkait pada kebutuhan akan ketuhanan, terkait dengan aspek religius. Meskipun demikian, hal ini, masih merupakan asumsi dasar yang masih memerlukan pembuktian dan penelitian ilmiah yang lebih lanjut. 
Pada kasus pasien penderita narkoba tidak ditemukan kecenderungan menumpuk warna dan bentuk, mereka cenderung lebih teratur baik dalam pembagian warna maupun dalam pengaplikasian warna. Pada teknik sapuan kuas, tidak terdapat agresifitas; sapuan kuas lebih tenang, tidak terkesan brutal, tidak tampak kasar dan samar-samar seperti pada penderita skizofrenia.

Visualisasi yang ditampakkan oleh penderita skizofrenia jauh lebih rumit, hingga mendekati kecenderungan abstrak yang ekstrem. Tidak jarang penulis tidak mampu menemukan deskripsi yang tepat untuk visualisasi yang ada pada gambar. Berikut pemaparan data visualisasi bentuk-bentuk lingkaran, segitiga dan persegi pada sampel gambar pasien.

Tabel 1 Pemaparan data visualisasi bentuk-bentuk lingkaran, segitiga dan persegi pada sampel gambar pasien (Sumber Madani Home Care, 2007).

\begin{tabular}{c|c|c|c|c}
\hline No & Nama & Segitiga & Lingkaran & Persegi \\
\hline 1 & Aswin & $\checkmark$ & $\checkmark$ & $\checkmark$ \\
2 & Dian & $\checkmark$ & $\checkmark$ & $\checkmark$ \\
3 & Norita & $\checkmark$ & $\checkmark$ & $\checkmark$ \\
4 & Yayan & $\checkmark$ & $\checkmark$ & $\checkmark$ \\
5 & H.Rudy & $\checkmark$ & $\checkmark$ & $\checkmark$ \\
6 & Evan & $\checkmark$ & $\checkmark$ & $\checkmark$ \\
\hline
\end{tabular}

\section{Gambar Sebagai Sebuah Diagnosa}

Pada kaitannya dengan aspek penyembuhan, seni memiliki kemampuan agar apa yang tidak mampu dikatakan dengan bahasa verbal pada umumnya, dapat dikomunikasikan dengan bahasa rupa. Dengan demikian, apa yang selama ini tak dapat dikatakan, menjadi terkatakan. Ungkapan ini senada dengan apa yang dikatakan oleh Margaret Naumburg, yaitu mengenai pernyataannya yang menilai bahwa terapi seni dapat diibaratkan sebagai "Pembicaraan Simbolik" atau Symbolic Speech. Dalam artian, melalui karya seni, apa yang tidak dapat dikatakan melalui kata-kata serumit dan sekompleks apapun akan dapat tersalurkan melalui kegiatan menggambar atau melukis. Pendekatan ini, yang seringkali disebut "Art Psychotherapy".

Maka endapan batin yang selama ini membludak dalam aspek ketidaksadaran, di keluarkan dalam bentuk karya visual. Maka hal ini dapat menjadi sebuah jalan agar keseimbangan dalam aspek ketidaksadaran menjadi seimbang atau stabil kembali, sedikit demi sedikit. Sehingga pada saat terapi berlangsung, pasien sebisa mungkin dicegah untuk kembali menumpuk endapan emosi dalam batinnya. Agar keseimbangan dalam aspek ketidaksadaran yang telah tercapai tidak kembali mengalami overloading. 
Selain itu pula, perbaikan-perbaikan dalam aspek ruhaniah, fungsi kreatif, kognitif, dan afektif dan psikomotorik juga diasah dalam terapi melukis. Karena, berkesenian adalah suatu jalan agar, koordinasi antara otak, hati, pikiran, dan aktifitas fisik kembali berjalan dengan selaras dan bekerja bersamaan. Dalam pengertian, saat seorang pasien merespon suatu perintah, dari terapisnya, maka otak secara otomatis akan segera memproses perintah tersebut, yang dominannya dalam bentuk image visual dalam otaknya. Kemudian, otak sebagai pusat koordinasi dari tubuh manusia, akan memberi suatu perintah bagi otot-otot yang bekerja pada sekitar tangan untuk segera merealisasikan image visual yang telah diprosesnya.

Pada saat inilah akan tampak, sampai sejauh manakah kerusakan fungsi otak itu terjadi karena ia akan mencerminkan sejauh mana koordinasi kerja otak-otot itu berlangsung, dengan luweskah atau dengan terpatah-patah. Maka yang tampak adalah, apakah gambar itu tampak overlapping, apakah sapuan kuasnya terpatah-patah, apakah akan tampak tekanan kuasnya akibat agresifitas yang meluap, atau apakah pasien bersangkutan akan sangat sering membagi-bagi bidang?. Maka tidak jarang penulis mempertanyakan kenapa seseorang sangat sering menumpuk bentuk dan warna, sedangkan pada pasien yang lain, ia cenderung membagi-bagi bidang, atau mengapa pasien yang satu sangat ekspresif dalam menyapukan kuasnya, dan sedangkan pada pasien yang lain tampak bersusah payah dan terpatah-patah.

Pada saat yang sama, kita telah mengetahui lazimnya dalam kegiatan berkarya seni, kondisi psikologis manusia akan secara spontan terkondisikan untuk mencurahkan segala aspek emosionalnya pada saat berkarya. Maka kemudian, pada saat yang bersamaan pula aspek afektif yang terkait dengan emosi akan terstimulasi, sehingga seiring berjalannya terapi, kebekuan emosional itu mencair, dan berfungsi seperti sediakala. Sedangkan aspek kognitif, distimulasi dalam bentuk upaya pasien agar, berbagai image dalam pikiran, divisualisasikan pada bidang gambar.

Untuk membuat visualisasi itu menjadi sesuatu dalam bidang gambar, dibutuhkan kemampuan kerja otak untuk mengorganisir kerja otot tangan sehingga sesuai dengan apa yang inginkan dalam image tersebut, ketika fungsi kerja otak telah membaik, maka otak akan memiliki kemampuan lebih untuk merespon bentuk sesuai dengan apa yang ada dalam realitas. Maka visualisasi pada gambar akan menampakkan sejauh mana terapi melukis telah memepengaruhi berbagai aspek yang mengalami kerusakan agar kembali menyeimbangkan fungsinya, yakni dalam berpikir (sinkronisasi kerja otak untuk mengorganisasi, memproses dan merealisasikan perintah yang masuk ke otak), berperasaan, (stimuli emosi dalam beraktivitas seni), dan psikomotorik (korelasi antara kerja otak dan kerja otot) 
Kemampuan berpikir, emosional, kemampuan psikomotorik, akan berjalan, atau katakanlah semua aspek tersebut akan secara spontan berfungsi secara serempak pada saat proses berkarya seni terjadi. Disini, seni memainkan fungsi sesungguhnya sebagai mediator, bukan sebagai agen utama penyembuh, dalam arti ia bersifat reflektif, memberi gambaran sampai sejauh manakah kerusakan aspek kejiwaan pada pasien, dan merekamnya. Sehingga terapis dapat menentukan pengobatan yang bagaimanakah yang sesuai bagi pasien yang dapat menghasilkan visualisasi tersebut. Dengan demikian, penulis memandang bahwa image-image yang tampak dapat pula berfungsi sebagai sebuah diagnosa. Seperti halnya pada ilmu kedokteran, ataupun psikologi. Seperti yang dijelaskan oleh penulis pada bab pendahuluan mengenai pernyataan Margaret Naumburg dalam bukunya Schizofrenic Art : Its Meaning in Psychotherapy:

"Modern psychiatry is becoming increasingly interested in the art productions of mental patients as a means both of diagnosis and therapy. Whether such art is employed as a projective test for diagnostic purposes or as an adajunct to therapy depends on several factors. If the art products are considered as aprojective technic for diagnosis, then planned art is often, although not always, requested of the patient. If however, the therapist regards spontaneous art expression as a means of therapeutic release and as a means of exploring the unconscious, he will relate such art productions of the patient to other forms of psychotherapy" [3]

Perbedaan antara kreativitas pada seniman kreatif dan pasien neurotik antara lain pada seniman kreatif, aspek berkarya, umumnya dikaitkan dengan aspekaspek artistik, intelek, konseptual, dll. Sedangkan pada pasien neurotik, aspek berkarya umumnya dikaitkan dengan aspek spontanitas, aspek reflektif, rekreatif, refreshing, terutama terkait dengan aspek kontemplatif, atau penyaluran. Aspek kontemplatif atau sublimasi inilah yang pada prosesnya amat berperan dalam memposisikan seni sebagai media penyembuh.

Selain hal tersebut juga terdapat warna, pada aspek pemilihan warna apakah seseorang, akan memilih misalkan warna biru atau kuning, hal tersebut berhubungan erat dengan emosi. Pada pengamatan penulis, warna juga turut memberi informasi tentang keadaan mental pasien. Umumnya, pada tahap awal terapi pasien cenderung memilih warna-warna yang mengarah ke warna-warna gelap, seperti misalkan pada warna biru dan hijau yang paling sering tampak pada gambar tahap awal pasien.

Kemudian, berangsur-angsur, apabila proses terapi berjalan dengan lancar, maka akan tampak pula perubahan pada warna-warna yang digunakan, dengan kata lain apabila terjadi perbaikan, maka kualitas kondisi kejiwaan pun kan 
semakin membaik, hal ini akan direspon oleh sisi kejiwaan manusia dan direpresentasikan melalui warna.

Tampak pada gambar tahap akhir warna-warna yang digunakan adalah warnawarna yang tampak cerah. Berikut ini adalah perbandingan visualisasi antara pasien neurotik dan pasien yang telah dikatakan sembuh atau telah kembali normal.

Tabel 2 Perbandingan visualisasi antara pasien Neurotik dan pasien yang telah dapat dikatakan sembuh atau normal.

\begin{tabular}{|c|c|}
\hline Ciri-ciri pada gambar pasien neurotik & Ciri-ciri pada gambar normal \\
\hline $\begin{array}{l}\text { 1. Warna dan bentuk divisualisasikan } \\
\text { tumpang tindih (overlapping) } \\
\text { 2. Bentuk dan komposisi absurd } \\
\text { 3. Pemilihan warna cenderung ke warna- } \\
\text { warna gelap dan suram } \\
\text { 4. Tidak terdapat objek real (nyata) } \\
\text { 5. Terdapat visualisasi bentuk-bentuk dasar } \\
\text { seperti segitiga, lingkaran persegi } \\
\text { 6. Pembagian bidang tampak kacau } \\
\text { 7. Brush stokes tampak kasar, tak } \\
\text { terkendali dan kacau } \\
\text { 8. Warna terkadang tampak samar }\end{array}$ & $\begin{array}{l}\text { 1. Warna dan bentuk divisualisasikan } \\
\text { dengan teratur } \\
\text { 2. Bentuk dan komposisi tampak } \\
\text { harmonis } \\
\text { 3. Pemilihan warna cenderung pada } \\
\text { warna-warna cerah, dan terdapat } \\
\text { keselaran antara terang dan gelap } \\
\text { 4. Terdapat dominasi bentuk-bentuk real } \\
\text { (nyata) } \\
\text { 5. Pembagian bidang tampak teratur } \\
\text { 6. Brush strokes terlihat tenang, teratur dan } \\
\text { solid } \\
\text { 7. Warna tampak terorganisir dengan rapi } \\
\text { tampak solid dan rapi }\end{array}$ \\
\hline
\end{tabular}

Metode penyembuhan total pada kejiwaan, tidak dapat bergantung pada terapi seni belaka. Namun terapi seni hanyalah salah satu aspek yang mendukung penyembuhan mental tersebut. Karena aspek kejiwaan manusia tidak begitu saja dapat mengandalkan aspek kreativitas belaka sebagai aspek yang dapat menyembuhkan, namun aspek fisik, ruhaniah, sosial, dan aspek kreatif harus berjalan secara seimbang. Maka dapat penulis katakan penyembuhan itu melibatkan keseluruhan aspek tersebut, dapat dikatakan terapi kejiwaan seharusnya berjalan secara holistik atau menyeluruh. Penyembuhan tidak dapat berjalan dengan timpang, dalam arti salah satu aspek lebih diutamakan dan aspek lainnya diabaikan. Jika demikian yang terjadi adalah penyembuhan yang bersifat parsial, sekalipun pasien pada akhirnya sembuh, namun penulis asumsikan akan menempuh waktu yang lebih lama.

Seni tidak berbeda dengan ilmu pengetahuan lainnya, yang berbasis pada penelitian dan pembuktian hipotesis. Saat ini banyak orang yang memiliki pemikiran bahwa seni hanyalah untuk seni, "art for art sake's". Tapi 
berdasarkan riset yang penulis lakukan, seni sama halnya dengan ilmu pengetahuan lainnya, hanya objek yang menjadi kajiannya berbeda. Seni juga merupakan ilmu pengetahuan yang dapat digunakan untuk kemaslahatan orang banyak. Terapi seni adalah salah satu cara untuk menyampaikan fungsi ini, yang telah terabaikan setelah sekian lama. Mengapa seni? Karena seni adalah salah satu kajian ilmu yang mempelajari korelasi antara tubuh, jiwa, dan hati, dan pikiran -selain ilmu psikologi tentunya- suatu ilmu yang memahami hakikat penciptaan suatu karya, serta memahami sisi keindahan dalam berbagai bentuk dari yang nyata hingga yang tak kasat mata.

Kemampuan ini diperlukan bagi jiwa manusia, karena selama beribu-ribu tahun seni telah menjadi mediator ulung bagi peradaban manusia tanpa mengenal institusi, dan berdasarkan fakta yang ada, seni tak pernah gagal dalam menjalankan fungsi ini. Kebanyakan manusia justru mengabaikan anugrah Ilahiah ini, dan tak memanfaatkannya dengan semaksimal mungkin. Segala hal tersebut adalah sesuatu yang fitriah dan naluriah. Yang membedakan seni dengan ilmu alam lainnya adalah, seni mempelajari segala sesuatu yang pada hakikatnya hanya dapat dirasakan, bukan disentuh.

Aktifitas berkesenian telah melatih manusia untuk mengeksplorasi kedalaman jiwa, serta memaksimalkan aspek intuitif. Seni adalah media yang tepat sebagai salah satu media untuk merekonstruksi aspek kejiwaan manusia. Dengan cara inilah penulis rasa, seni dapat menyumbangkan fungsinya dalam masyarakat. Dan mendobrak dinding yang membatasi antara masyarakat awam dan masyarakat seni.

Karena itulah seni juga dapat menjembatani orang-orang dengan berbagai keterbatasan, dan dapat menjadi penyambung lidah bagi orang-orang yang tersisih dari masyarakat karena keterbatasan mereka. Dengan seni pula kita dapat memberikan kesempatan bagi mereka untuk mengungkapkan cara berpikir mereka, atau bagaimana cara mereka memandang dunia dari sudut pandang mereka, ataupun untuk mengetahui ketakutan dan kesedihan apa yang mereka alami. Untuk membuat orang dapat melihat dari visi mereka, mendengar dari pendengaran mereka, dan berbicara dengan bahasa mereka. Seni dapat memberikan suatu lahan bagi mereka yang "unspoken", suatu lahan yang tak dapat diberikan oleh ilmu pengetahuan lainnya.

Seni, seringkali dipandang sebagai suatu aktifitas yang murni berkitan dengan bakat, hal ini tidak sepenuhnya salah. Namun seni juga merupakan suatu ilmu pengetahuan yang juga memerlukan ketelitian yang luar biasa, terkait pada eksperimen dan observasi, serta tidak dapat dilepaskan sepenuhnya dari keterkaitannya dengan ilmu pengetahuan lainnya Hal ini tentunya, tanpa mengabaikan aspek logis, intelektualitas, berbasis pada penelitian yang juga 
tidak beranjak dari kaidah ilmu pengetahuan. Seperti halnya Leonardo da Vinci yang menemukan pembagian proporsional tubuh manusia dengan jalan membedah mayat, yang mana hal ini dekat sekali dengan ilmu biologi dan kedokteran. Kemudian ia menemukan perhitungan yang akurat dalam skala tubuh manusia, yang kemudian diaplikasikan kedalam gambar yang memenuhi kaidah naturalis dalam mengambar proporsi tubuh manusia dalam image dua dimensional.

Seni merupakan suatu anugrah yang perlu disyukuri dengan sebaik-baiknya karena tidak semua manusia dapat terlahir dengan anugrah tersebut. Sehingga dapat menghasilkan seseorang yang dapat memaksimalkan daya intuitif, dan ketajaman insting dan nalurinya.

\section{Simpulan}

Seni dapat menjadi sebuah jalan bagi kesembuhan mental manusia, melalui sebuah unsur yang dikenal dengan istilah Katarasis. Melalui aspek ini pula, dapat kita ketahui, seperti apakah visualisasi dari alam bawah sadar manusia. Serta terdapat pola-pola yang menandakan adanya alur yan dapat dijadikan tolak ukur kesembuhan pasien Skizofrenia dan Narkoba. Selain itu terdapat visualisasi dari bentuk-bentuk dasar seperti segitiga, lingkaran dan persegi secara terus menerus, terutama ketika pasien masih dalam tahap awal terapi

Setelah meneliti berbagai aspek yang berkaitan dengan terapi seni, penulis ingin menyarankan agar baik itu kepada peneliti seni maupun psikolog agar saling mempertukarkan ilmu dibidangnya masing-masing dengan maksud agar ilmu terapi seni dapat lebih berkembang dan lebih dikenal oleh masyarakat, baik itu oleh masyarakat seni, psikologi, maupun oleh masyarakat awam. di Indonesia. Selain itu agar kedua ilmu tersebut, yakni psikologi dan seni, saling berkorelasi satu sama lain, yang mana penulis telah melihat beberapa kesamaan antara kedua disiplin ilmu tersebut, meskipun pada kenyataannya masih terdapat jarak dan perbedaan sudut pandang yang tajam antara peneliti seni dan psikologi.

\section{Referensi}

[1] Malchiodi,Cathy. 1998, The Art Therapy Sourcebook, New York, Lowell House Book, hal. 3-4.

[2] Simon, R.M., 1997, Symbolic Images In Art As Therapy, London, Routledge.

[3] Naumburg, Margaret, 1950, Schizofrenic Art: Its Meaning in Psychotherapy. New York, Grune and Stratton Inc.

[4] Anwar, Anisa, 2002, Aspek Terapi Seni Pada Upacara Adat di Indonesia, Bandung, ITB. 


\section{Lain-lain}

Arsip Madani Home Care, 2004

Http:// www.Healingthroughcreativity.org 23/11/06, 19:09 